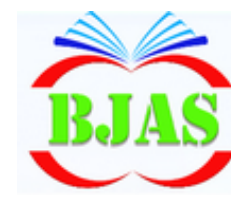

ISSN $1814-5868$
Available online at http://bjas.bajas.edu.iq

https://doi.org/10.37077/25200860.2020.33.2.06

College of Agriculture, University of Basrah

Basrah J. Agric. Sci., 33(2): 67-79, 2020

\section{Basrah Journal of Agricultural Sciences}

E-ISSN: 2520-0860

\title{
Development of Antioxidant Activity of Potato Starch Edible Films Incorporating with Rosemary Rosmarinus officinalis L. Oil and Using it in Packaging Beef Pattis
}

\author{
Batool M. Alansari \\ Department of Food Sciences, College of Agriculture, University of Basrah, Iraq \\ *Corresponding author:batool.mahmod6@gmil.com \\ Received 22 March 2020; Accepted 16 August 2020; Available online 17 October 2020
}

\begin{abstract}
The purpose of this study is to investigate the antioxidant activity of edible films prepared from starch extracted from potatoes and corporate with essential oil extracted from rosemary leaves at 2,4 and 6\% concentration and used in the packaging of beef patties stored at $4-6{ }^{\circ} \mathrm{C}$ for 10 days. The results showed that antioxidant activity, reducing power and chelating of ferric ion increased with increasing oil concentration 70.1, 66.5, 73.7\% respectively at 6\% oil concentration. Thermogravimetric analysis and diagnosis of active groups of simple and oil corporate films were also performed. Changes in peroxide values of beef patties covered with simple starch films and films corporate with oil were followed. The results showed that the peroxide values were lower in the covered treatments compared to the control treatment that did not contain oil. The effect of adding rosemary oil increased prolonging the duration of storage of beef patties as long as storage.
\end{abstract}

Keywords: Edible film, Antioxidant, Starch, Thermogravimetric analysis, Essential oil.

\section{Introduction}

Adding antioxidants is a traditional way to control the deterioration of oxidation of meat and meat products. Industrial antioxidants have long been used effectively in a variety of foods for this purpose, however the overall rejection of industrial food additives by the consumer because of potential unsafe effects on health led to the search for natural alternatives to industrial antioxidants (Camo et al., 2008). The utilization of varied herbs and spices and their extracts as natural antioxidants in many types of meat and meat product is effective in controlling oxidative damage and prevent the growth of bacteria and corruption and thus prolong their shelf life (Shan et al., 2009). Research in this field focuses on the use of biodegradable packaging materials due to the negative environmental impact of plastic represented by edible films and coatings, which are good carriers for many food additives including antioxidants to control the changes caused by the oxidation process in food products during storage and it is among the most important factors responsible for the loss of quality in meat products (Ponce et al., 2008). The incorporation of natural antioxidants into edible films and coatings modifies their composition and improves their functions and applicability in food (Coskun et al., 2014). 
The use of industrial antioxidants in food has been avoided because of its possible hazardous effect. Instead, this used a wide range of natural antioxidants such as essential oils and plant extracts which were corporates with edible films to improve their biologically active properties (Kadri et al., 2011). Essential oil is natural compounds extracted from plants that have antimicrobial and antioxidant properties, which were included in food processing as antioxidant activity (Pirouzifard et al., 2019). Among these oils is rosemary plant oil. Rosemary (Rosmarinus officinalis L.) is of considerable importance in terms of its great an important medicinal and aromatic value. This plant is an evergreen perennial shrub belonging to the Lamiaceae family. It is an evergreen perennial shrub belonging to the Lamiaceae family (Kadri et al., 2011). Native to the Mediterranean region, rosemary is now cultivated around the world due to its use as a natural food preservative and flavouring agent. The secret behind the preservative and the therapeutic abilities due to its essential oil and extract. Rosemary oil whose anti-oxidant activity is due to the active compounds. The major constituents of monoterpenes were 1,8cineole $(35.32 \%)$, borneol $(9.37 \%)$, camphor (8.97\%), $\alpha$-thujone $(6.42 \%)$. However, the principal components of monoterpene hydrocarbons were $\alpha$-pinene $(7.90 \%)$ and camphene $(3.35 \%)$ (Kadri et al., 2011). The anti-oxidant activity of this oil due to the active compounds present in this oil, and adding it to animal meals delays the process of oxidation of fats in meat (Atares \& Chiralt 2016). Packaging using edible films corporate with natural plant extracts has become a successful industrial application for controlling oxidative changes in natural meat products. Films and coatings corporate with natural antioxidants help enhance the sensory properties of food and improve the quality of food products by increasing storage duration (Li et al., 2014). Starch can produce biodegradable films at low cost and on a large scale. Furthermore, starch-based materials may contribute to the utilization of nonrenewable resources and the environmental impact caused by synthetic plastics (Perazzo et al., 2014). Pirouzifard et al. (2019) found that the potato starch composite film containing zedo gum and salvia essential oil showed antioxidant properties and suitable to be used in the food packaging industry.

The present study aimed to develop the antioxidant activity of starch films which are corporate with oil extracted from rosemary leaves and study of its storage capacity, thermal stability, estimation of effective groups, the use in packaging beef patties stored at $4-6^{\circ} \mathrm{C}$ for 10 days.

\section{Materials \& Methods}

All the chemicals used in the research are analytical types. The materials used in the preparation of edible films were brought from the local market (potatoes, rosemary leaves). The leaves were cleaned of impurities and stored in a glass container until used.

\section{Extracting starch from potatoes}

Potato starch was extracted according to the method of Bente et al. (2006) taking $1 \mathrm{~kg}$ of well-washed potatoes, removing its outer shells, then cutting into small pieces and mixing with 1 litre of water in a blender. The mixture was filtering through a piece of two layers of gauze cloth. The granules were held with water several times and centrifuged at a speed of $2000 \mathrm{rpm}$ for 10 minutes. Then purified starch granules were dried at laboratory temperature for 24 hours and stored in plastic containers until used. 


\section{Preparation of the film-forming solution}

The method was described by Mali et al. (2006) in the preparation of potato starch film by casting method was followed, the film solution was prepared by dissolving the starch with distilled water $\left(3 \mathrm{~g} .100 \mathrm{ml}^{-1}\right.$ solution) and adding $40 \%$ glycerol as a plasticizer $\left(\mathrm{g} .100 \mathrm{~g}^{-1}\right.$ starch) and the volume was completed to 100 $\mathrm{ml}$ with distilled water. All components were mixed using a hot plate magnetic motor (Hot plate- Magnetic Stirrer) supplied by the German company Gellenkamp, until the temperature reached $95^{\circ} \mathrm{C}$ and within 10 minutes. The solution was cooled to $50^{\circ} \mathrm{C}$ and the film solution was poured into plastic plates. Starch gelatinization occurs at $60^{\circ} \mathrm{Cand}$ the final characteristics are strongly influenced by starch and plasticizer interaction. The dishes were dried at room temperature $25^{\circ} \mathrm{C}$ for 24 hours and the films were removed from the dishes and placed in polyethylene bags and stored in the refrigerator until used.

\section{Oil extraction from rosemary leaves}

The volatile oil was extracted in the laboratory of essential oils and medical at the College of Agriculture / University of Basrah, using water distillation according to the method mentioned by (Moss, 2003) was used (Clevenger) and conductor to a round glass flask size 1 litre weighed $30 \mathrm{~g}$ of leaves Rosemary and soaked in $30 \mathrm{ml}$ of petroleum ether in a flask with a cover and stored at room temperature for the next day. The distillation was then performed 2.30 hours until the largest amount of volatile oil was obtained.

\section{Preparation of rosemary composite films}

The film with oil was prepared by adding rosemary oil of $2,4,6 \%$ (fat/starch weight) to the potato starch film solution. The method described by Veena et al. (2015) was followed in the preparation of the composite film. Rosemary essential oil at three different concentrations $(2 \%, 4 \%$ and $6 \%)$ was added slowly with continuous stirring to film solution. The solution leaves until the temperature reached $95^{\circ} \mathrm{C}$ and for 10 minutes. The solution was cooled to $50^{\circ} \mathrm{C}$ and poured into plastic plates. The dishes were dried at room temperature $25^{\circ} \mathrm{C}$ for 24 hours. Then films were removed from the dishes and placed in polyethylene bags and stored in the refrigerator until used.

\section{Study of effective groups by Fourier transform infrared spectroscopy technique (FTIR)}

The effective groups of film samples were diagnosed after drying and grinding well in a ceramic mortar. The dried and powdered samples were mixed with 100:1 potassium bromide and pressed into the form of a thin tablet. The model was pressed into the infrared device supplied by the Japanese company Jasco used in the Department of Chemistry, College of Science, University of Basrah, according to Melo et al. (2011).

\section{Thermo Gravimetric Analysis (TGA )}

Thermogravimetric analysis of films was carried out at temperature range extended from room temperature to $700^{\circ} \mathrm{C}$ at a rate of $10^{\circ} \mathrm{C} \cdot \mathrm{min}^{-1}$ under an atmosphere of nitrogen 20 ml.min ${ }^{-1}$ using the Q50V20.13 Build 39 TGA. It is located in the Department of Chemistry, College of Science, the University of Basrah according to the method mentioned by Senna et al. (2011). The samples were dried well and crushed with a ceramic mortar.

\section{Determination of antioxidant activity}

The determination of antioxidant activity was estimated by using a linoleic acid system for essential rosemary oil and film solutions 
proposed by Kudo et al. (2009). Concentrations of film solutions containing rosemary oil were prepared at a concentration of $2,4,6 \%$. Then a mixture of $4.1 \mathrm{ml}$ linoleic acid $2.5 \%$ ethanol concentration and $4 \mathrm{ml}$ of the sample (oil, simple potato starch film solution, rosemary composite film solution, 8 $\mathrm{ml}$ phosphate buffer solution 0.05 molar at $\mathrm{pH}$ 7 and $3.9 \mathrm{ml}$ distilled water) was prepared.

The mixture was incubated at $40^{\circ} \mathrm{C}$ for 24 hours in opaque containers. Thiocyanate oxidation was estimated by adding $0.1 \mathrm{ml}$ of this mixture to $9.7 \mathrm{ml}$ ethanol $75 \%$ concentration and $0.1 \mathrm{ml}$ ammonium thiocyanate $30 \%$ concentration. $0.1 \mathrm{ml}$ ferrous chloride $3.5 \%$ hydrochloric acid was added three minutes later then the absorption was measured at $500 \mathrm{~nm}$. The control sample was prepared in the same way above by adding distilled water without the sample. The percentage of inhibition of linoleic fatty acid peroxides was calculated according to the following equation:

Antioxidant activity $\%=$

$\left[1-\left(\frac{\text { Sample absorbance }}{\text { Control sample absorbance }}\right)\right] \times 100$

\section{Ferric Reducing Antioxidant Power}

The reduction potential of film solutions was determined by using the potassium ferricyanide ferric chloride method (Oyaizu, 1986). The control sample was prepared by adding all the previous materials, except the addition of simple and composite film solution. The absorption was measured at 700 $\mathrm{nm}$. The following equation was applied:

Reduction power $\%=$

$100-\left[\frac{\text { The absorbance of the model }}{\text { The absorbance of the control sample }}\right] \times 100$

\section{Chelating of ferrous ion ability assay}

Chelating of ferrous ion was measured by inhibiting the formation of $\mathrm{fe}^{+2}$ - ferrozine complex after treatment of test material with $\mathrm{fe}^{+2}$ following the method of $\mathrm{Su}$ et al. (2008). Absorption was measure at $562 \mathrm{~nm}$. The control sample was prepared in the same way except for the addition of the sample. The chelating of ferrous ion was calculated according to the following equation:

Chelating of ferrous ion $\%=$

$1-\left[\frac{\text { The absorbance of the model }}{\text { The absorbance of the control sample }}\right] \times 100$

\section{Application}

\section{Packaging beef patties with simple starch film and a composite starch film with Rosemary oil by 2, 4 and $6 \%$}

Prepared beef patties from minced beef by electric mincing machine and added to the fat by $10 \%$ and minced meat again with the fat for homogenization. Salt was added by $2 \%$ to the minced meat product, then the meat was divided into five treatments A, B, C, D and E. As treatment $\mathrm{B}$ was covered with a simple potato starch film solution, treatment $\mathrm{C}, \mathrm{D}, \mathrm{E}$ was immersed in a compound potato starch solution with rosemary oil at a concentration of 2, 4 and $6 \%$. As for treatment A, it was left without packaging to represent the control sample. The immersion process was carried out by immersing the meat patties in the film solution for five minutes, then removing the patties from the solution and placing them on a mesh tray of metal for 10 minutes, then they were left at room temperature until dry and then Beef patties were placed in polyethylene bags and stored in the refrigerator at $4-6^{\circ} \mathrm{C}$ for 10 days during which the change in peroxide number values was monitored. Beef patties were placed in polyethylene bags and stored in the refrigerator at $4-6^{\circ} \mathrm{C}$ for 10 days during which the change in peroxide number values was monitored. 


\section{Peroxide value determination}

Peroxide value determination was estimated for beef patties as stated in AOAC (2000) for each treatment of the refrigerated samples and a period 10 days as measured peroxide value on the second day and the fifth day and the tenth day. The value of peroxide was then calculated from the following equation:

Peroxide value $=$ mI of Na2S304 X 0.01 standard x 1000

$\mathrm{Wt}$. of sample

\section{Statistical analysis}

Statistical analysis of treatment was conducted using a one-way ANOVA design (SPSS, 2019, version 24). Each treatment had three replicates. The significant level considered as 0.05 .

\section{Results \& Discussion}

\section{Simple Starch Film:}

According to visual examination, the obtained films were transparent, odourless, easy to handle. They were easily removed from the casting plates as in fig. (1) and this is similar to what Suput et al. (2016) obtained.

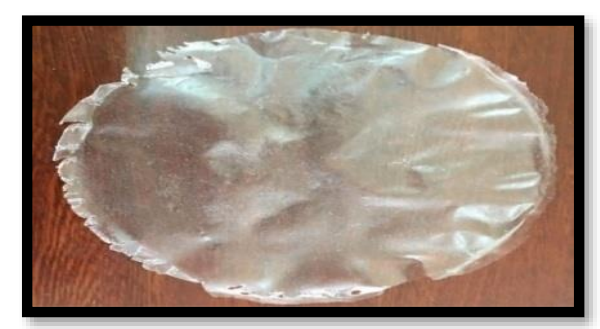

Fig. (1): Simple Potato Starch Film.

\section{Starch films extracted from potatoes and incorporated with rosemary oil}

The starch films extracted from potatoes and compounds with oil extracted from rosemary leaves were distinguished to easily remove from the mould and the films acquired the appropriate strength as a result of increasing the thickness of the films compared to the simple film without added oil as in fig. (2). This was due to the increase of the total solids of the film after the drying process and this was similar to what he found Resianingrum et al. (2016).

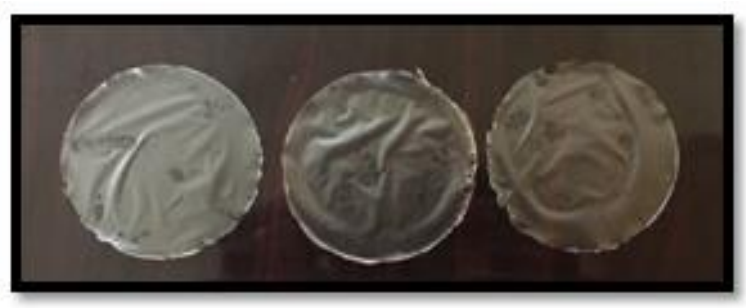

Fig.(2): Starch films installed with rosemary oil.

The thickness of the film prepared from cassava starch increased when the essential oil of cinnamon bark was added to Resianingrum et al. (2016) Indicated that the thickness of the cassava starch film increased by increasing the concentration of lemon essential oil from oils to starch films might induce a plasticizing effect that can improve the mechanical integrity of resulting films (Veena et al., 2015).

\section{Diagnostics of FT-IR Spectroscopy}

FT-IR spectra could be used to determine molecular reactions and certain chemical components. Figs. (3-6) illustrate the results of the diagnosis of effective combinations of simple potato starch films and rosemary films at 2, 4 and $6 \%$ concentration. A wide beam of the spectrum at the wavelength of $3414.12 \mathrm{~cm}^{-}$ ${ }^{1}$ was observed due to the amplitude vibration of the hydroxyl groups $\mathrm{OH}$. The intensity of this bundle varies according to the type of the reactants and the intensity of the reaction, and it expresses the increase of the hydrogen retention of the free and hydroxyl groups associated with the film-forming molecules (Haq et al., 2014), while the bands of the spectrum were observed at wave numbers 2931.90, 2889.46 and $2928.04 \mathrm{~cm}^{-1}$. These 
Alansari / Basrah J. Agric. Sci., 33(2): 67-80, 2020

peaks are attributed to the expansion and bending positions of the $\mathrm{CH}_{2}$ aliphatic groups. at wavelength $1643 \mathrm{~cm}^{-1}$ a band appeared due to the amplitude oscillation of the carbonyl group $\mathrm{C}=\mathrm{O}$ and the intensity of this region was often affected by the hydrogen bond (Wang et al., 2010). The peaks are shown at range $1022.31,1026.16$ and $1157.33 \mathrm{~cm}^{-1}$ were due to the curvature of the $\mathrm{C}-\mathrm{O}$ and $\mathrm{C}$ $\mathrm{O}$ group resulting from the reaction of the glycerol added as a plasticizer (Garrido et al., 2013).

Suput et al. (2016) noticed a very good correlation of the linear function, which was determined between the number of essential oils for both black cumin and black pepper and the FTIR spectra of the starch films while increasing the amount of oil. He mentioned deformation that occurs in the vibrations is due to the different functional groups present in both oils.

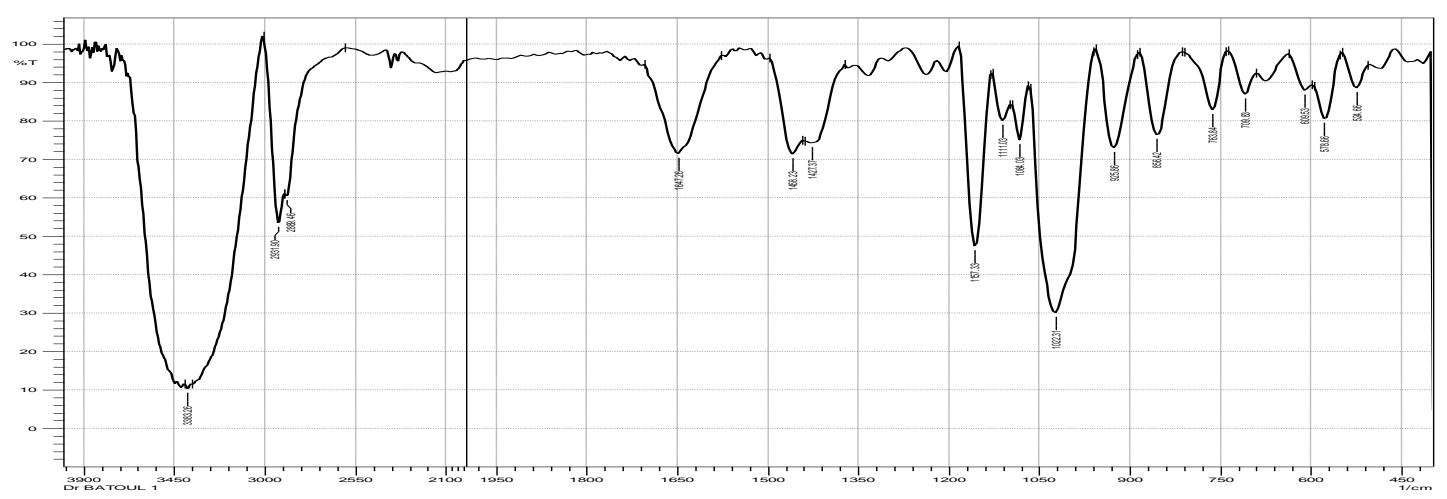

Fig. (3): Infrared spectrum of the simple potato starch film.

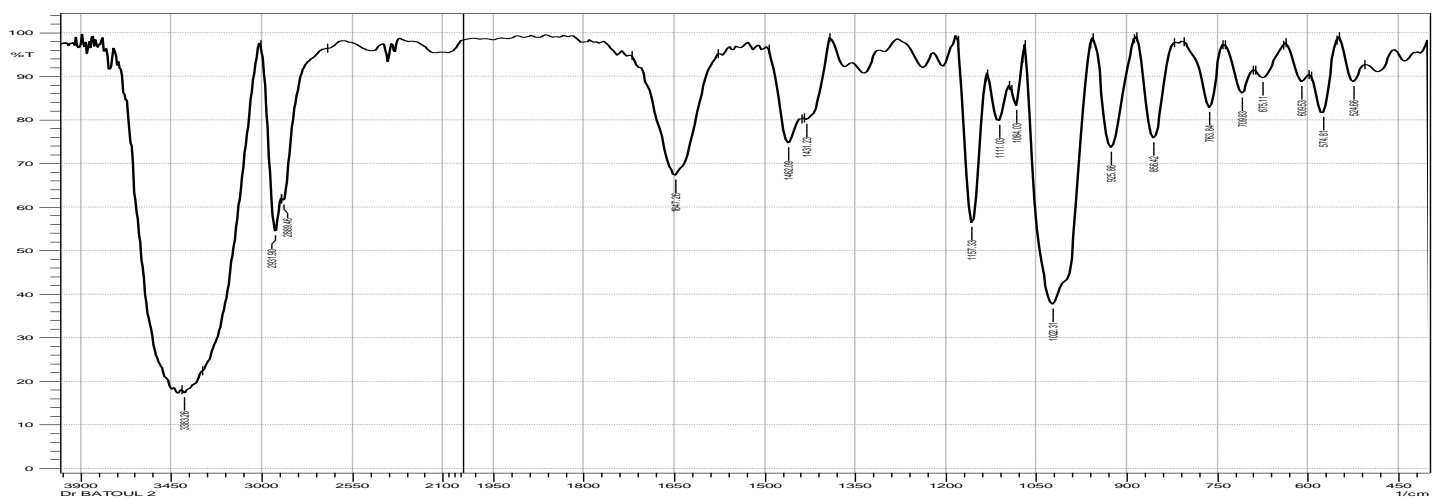

Fig. (4): Infrared spectrum of membrane potato starch with rosemary oil at a concentration of $2 \%$.

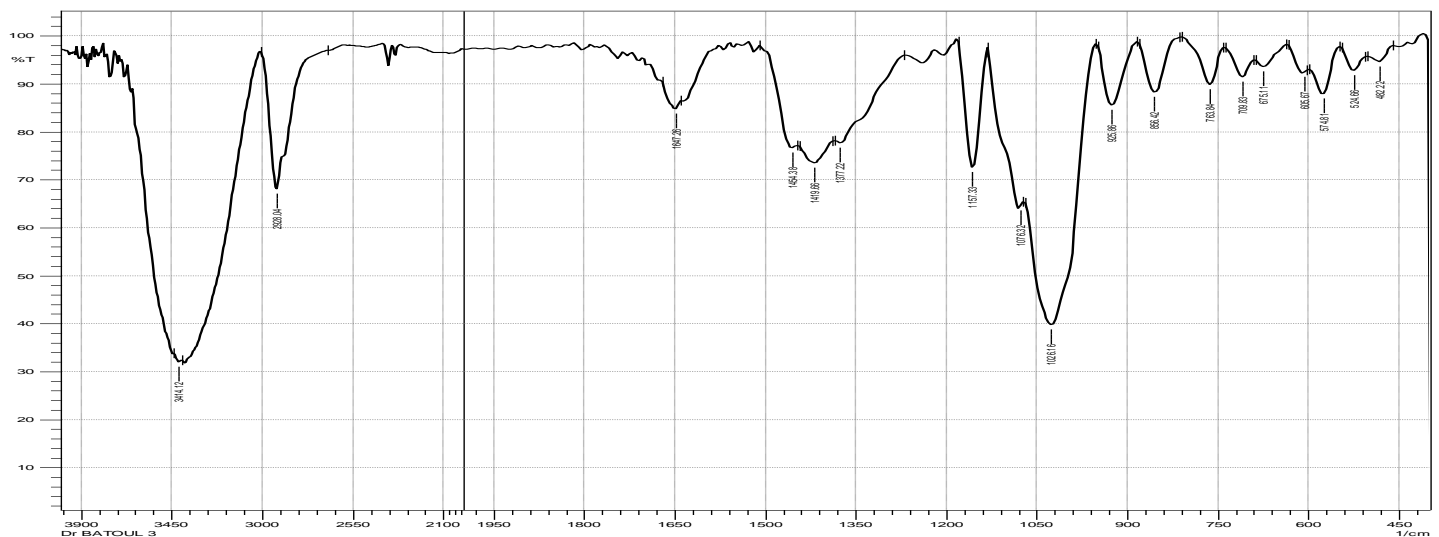


Fig. (5): Infrared spectrum of the compound potato starch film with rosemary oil at a concentration of $4 \%$.

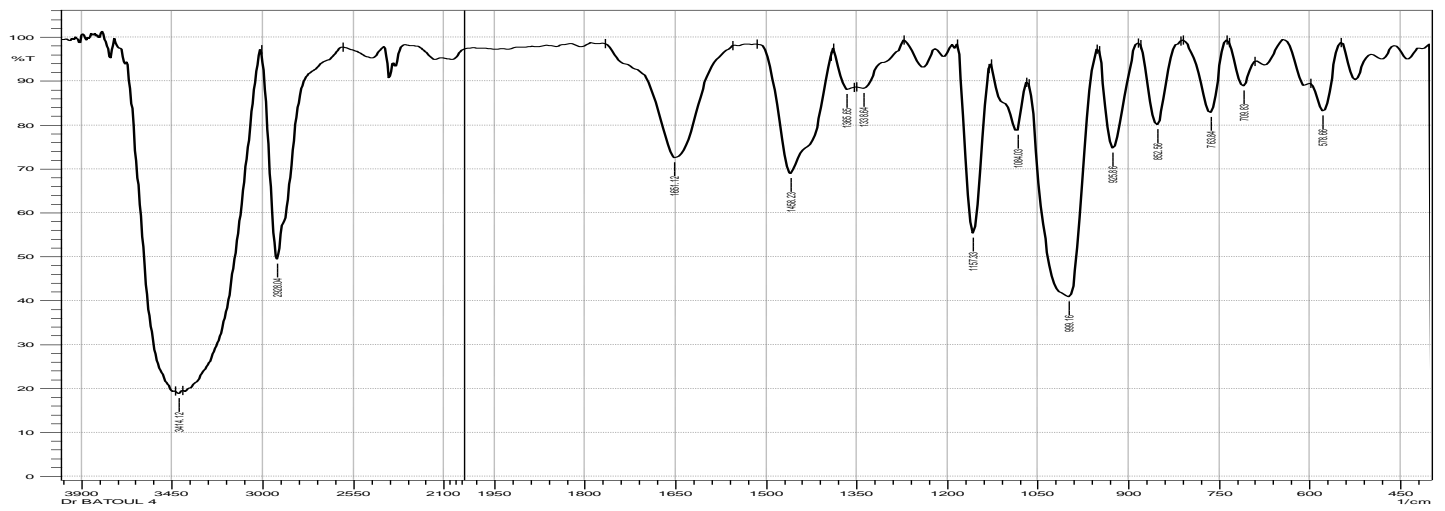

Fig.(6): infrared spectrum of the compound potato starch film with rosemary oil at a concentration of $6 \%$.

\section{Thermo Gravimetric Analysis (TGA)}

Figs. (7-10) illustrated the gravimetric curves for the thermal stability of the potato starch films composite with rosemary essential oil of $2,4,6 \%$. It was a technique in which the change in the mass of the sample was estimated by temperature, as weight loss and polymer degradation was observed in several stages, the first stage was a loss of weight by $2-10 \%$ at a temperature of $180.89,200.10$ and $325.15^{\circ} \mathrm{C}$. The reason for the loss of weight was due to the disintegration and evaporation of free water associated with any loss of moisture in the base material of the film as the starch, starch had one stag of disintegration at approximately $300^{\circ} \mathrm{C}$. The second stage was the main disintegration stage and started at a temperature of $300-400 \mathrm{C}$ where the maximum disintegration occurred 338.47, 357.69 and $353.84^{\circ} \mathrm{C}$ as in figs. (8-10).

Fig. (7) shows the thermal decomposition curve of the simple potato starch. Weight loss and decomposition of the compound were observed from the figure in several stages.

The first loss occurred at a temperature of 63.66C, which was attributed to the loss of moisture in the starch and the second major stage of the disintegration of starch, which started at a temperature of $180.89 \mathrm{C}$ the maximum disintegration of starch occurred at a temperature of $338.47^{\circ} \mathrm{C}$. The reason for the disintegration was attributed to several reasons, which were the breakdown of most of the molecular structure of starch, which included the drying and polymerization of sugary rings, as well as the random breakage of the glycoside bonds, and the loss of bleeding water and the disintegration of the glycerol as a result of its evaporation or the presence of some incomplete crystallization. the second step occurred at $280{ }^{\circ} \mathrm{C}$ and the maximum degradation peak at $312{ }^{\circ} \mathrm{C}$ was related to starch chain decomposition. The second stage was the main disintegration stage and started at a temperature of 300$400^{\circ} \mathrm{C}$ where the maximum disintegration occurred $338.47,357.69$ and $353.84^{\circ} \mathrm{C}$ as in figs. (8-10), which lost about $14-25 \%$ of its weight. The reason was due to the amount of base material remaining in the simple films being more compared to the amount in the films with oil added as a result of the change that occurred in the polymer network structure, which led to a decrease in the tensile strength of the film. While the amount of base material remaining in the simple film was higher than the amount. The amount of base material remaining in temperature 400 $500^{\circ} \mathrm{C}$ caused the removal of the carboxyl 
group as well as the decomposition of $\mathrm{H}$ and $\mathrm{CH}_{2}$ bonds, the deterioration of the side chain and the loss of $\mathrm{CO}_{2}$ which disintegrated at different temperatures sit could withstand the temperature up to $700{ }^{\circ} \mathrm{C}$. Therefore, had high thermal stability while the thermal stability of the oil films decreased due to the change in the structural composition of the film material. Diaz- Galido et al. (2020) stated that the maximum decomposition of the corn starch films incorporated with different concentrations of cinnamon oil and the emulsified substance (mucilage) was at a temperature of $312{ }^{\circ} \mathrm{C}$, as two phases of decomposition appeared, the first degradation step occurred up to $180^{\circ} \mathrm{C}$,

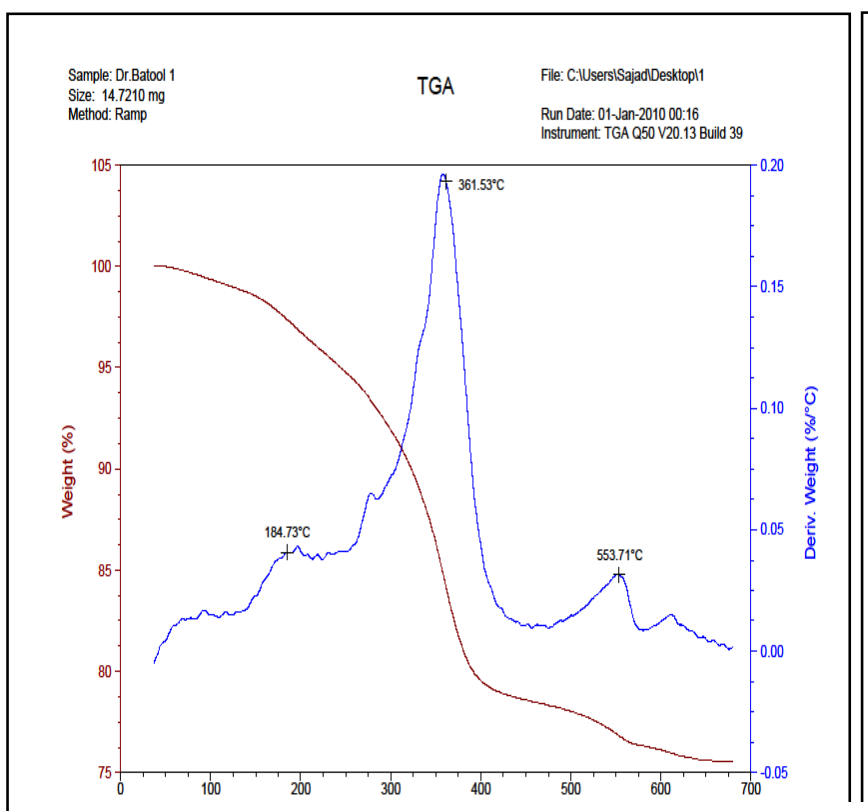

Fig. (7): Gravimetric decomposition of the simple\& plasticized starch membrane with glycerol $40 \%$.

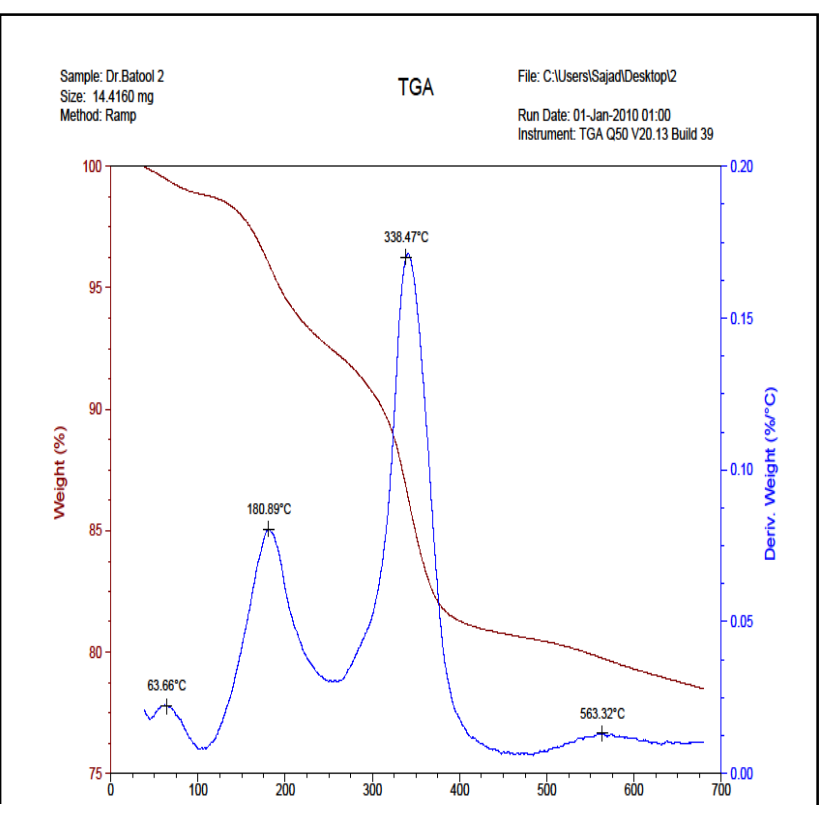

Fig. (8): Gravimetric decomposition of the potato starch membrane combined with rosemary oil $2 \%$.

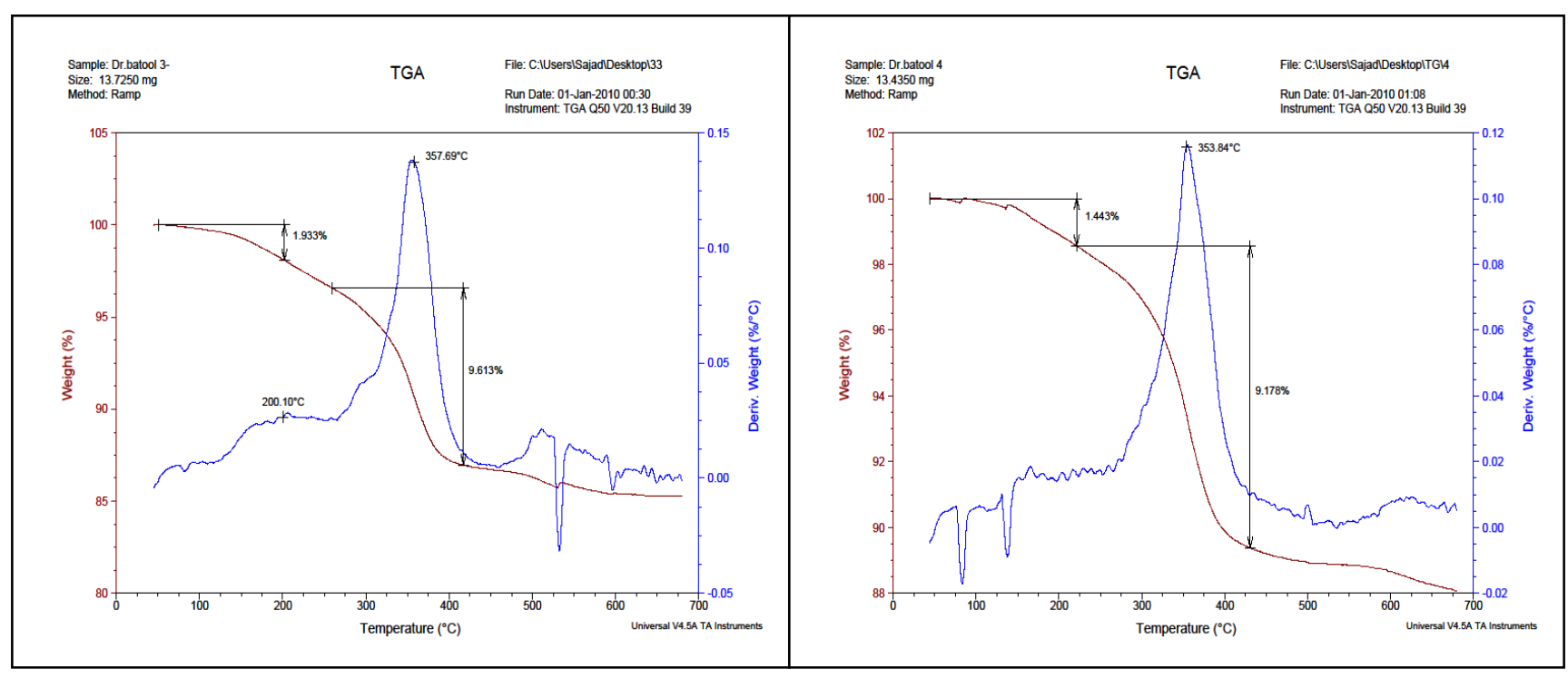

Fig. (9): Gravimetric decomposition of the potato starch film, which is combined with rosemary oil $4 \%$.

Fig. (10): Gravimetric decomposition of the potato where bonded and boundless water was released whereas the second step occurred at starch film, which is combined with rosemary oil $6 \%$. 
$280{ }^{\circ} \mathrm{C}$ and maximum degradation peak at $312{ }^{\circ} \mathrm{C}$ were associated. With starch chain decomposition and Diaz- Galido et al. (2020) observed that the addition of emulsion did not affect the thermal degradation profile of thermoplastic starch.

The process of gravimetric thermal decomposition facilitated a knowledge of the stability of films. and their applicability in various application fields (Perazzo et al., 2014).

\section{Antioxidant activity}

Table (1) demonstrates the results of the antioxidant activity of rosemary oil and simple potato starch film solution with rosemary oil concentrations of $2,4,6 \%$. It was noted that the antioxidant activity of rosemary oil was $75.3 \%$, due to the presence of some compounds that have antioxidant activity. Most of the studies reported that the antioxidant activity of essential oils is caused mainly by phenolic compounds (Suput et al., 2016). According to Kadri et al. (2011), major oil components of rosemary oil included 1,8 cineole, $\alpha$-pinene, $\beta$-pinene, camphor, $\alpha$ thujone and the-thujone (Kadri et al., 2011); while simple potato starch films showed some antioxidant activity, they were $24.6 \%$ due to the presence of free radicals that could react with the remaining hydroxyl $(\mathrm{OH})$ groups in the starch that formed large molecules. As $(\mathrm{OH})$ groups can form $\left(+\mathrm{OH}_{2}\right)$ groups by absorbing the hydrogen ion from the solution (Tooraj et al., 2012). The antioxidant activity of oil films increased by increasing the concentration of oil( $56.4,64.2,70.1) \%$ at concentrations $(2,4,6) \%$. Significant differences in antioxidant activity were observed between the simple film and embedded films as well as significant differences in antioxidant activity were observed between films with different oil concentrations at probability level $(\mathrm{P}<0.05)$. Pirouzifard et al. (2019) found that the potato starch composite film containing Zedo gum and Salvia essential oil showed excellent physical and antioxidant properties and had an excellent ability to be used in the food packaging industry. Al-Hashemi et al. (2020) found that the antioxidant activity of millet starch films incorporated with essential clove oil at a concentration of 1,2 and $3 \%$ was due to phenolic compounds which present in the essential oil as Eugenol and the activity increased $15.96 \%$ with an increase in the essential oil concentration $3 \%$ compared to the activity of a simple starch membrane $0.3 \%$.

\section{Reducing power}

Table (1) also indicates that the reduction potential of oil was $76.4 \%$, while the reduction rate of the simple starch film was $21.8 \%$. Whereas the reduced strength of the composite film with oil concentration of 2,4 and $6 \%$ increased by increasing the oil concentration as it was 55.1, 61.2 and 66.5\% respectively. The reason for reductive power was due to the presence of active compounds involved in film synthesis, which reduced the ferric ion $\mathrm{Fe}^{+3}$ to the ferrous ion $\mathrm{Fe}^{+2}$ to avoid free radical reproduction by granting an electron, which in turn interacted with free radicals and turn them into more stable compounds and stopped the process of reproduction (Ruiz- Navajas et al., 2013).

\section{Chelating ferrous ion}

It can be seen from the table (1) that the ferrous ion is binding capacity of rosemary oil $79.1 \%$, While the ferrous ion bonding rate of 
Alansari / Basrah J. Agric. Sci., 33(2): 67-79, 2020

Table (1): Antioxidant activity, reducing power, the ability to bind ferrous of rosemary oil for simple and compact starch films, EO= essential oil.

\begin{tabular}{|c|c|c|c|}
\hline $\begin{array}{c}\text { Treatment (EO } \\
\text { concentration \%) }\end{array}$ & Antioxidant activity\% & Reducing power \% & $\begin{array}{c}\text { The ability to bind } \\
\text { ferrous ion \% }\end{array}$ \\
\hline 0 & $24.6 \mathrm{~d}$ & $21.8 \mathrm{~d}$ & $31.7 \mathrm{f}$ \\
& \pm 3.37 & \pm 3.43 & \pm 4.33 \\
\hline 2 & $56.4 \mathrm{c}$ & $55.1 \mathrm{c}$ & $53.6 \mathrm{~d}$ \\
& \pm 3.49 & \pm 4.41 & \pm 3.61 \\
\hline 4 & $64.2 \mathrm{~b}$ & $62.2 \mathrm{~b}$ & $62.4 \mathrm{c}$ \\
& \pm 3.98 & \pm 4.76 & 73.22 \\
\hline 6 & $70.1 \mathrm{a}$ & $66.5 \mathrm{~b}$ & \pm 4.36 \\
\hline EO & \pm 3.46 & \pm 4.88 & $79.1 \mathrm{a}$ \\
& $75.3 \mathrm{a}$ & $76.4 \mathrm{a}$ & \pm 4.91 \\
\hline
\end{tabular}

Vertically different letters mean significantly differ at $\mathrm{P}<0.05$ level.

the simple film was $31.7 \%$, and the susceptibility of the added film with oil to bind ferrous ion increased 53.6, 62.4 and $73.7 \%$ by increasing the oil concentration respectively. This was due to the presence of active compounds in rosemary oil and film solution, which have antioxidant activity based on the composition of molecules containing hydroxyl aggregates which has a chelating property to bind catalytic metal ions (iron and copper) so it inhibited the formation of free radicals and therefore was not oxidation process had occurred. Al-Hashemi et al. (2020) reported that phenolic compounds are receptors for free radicals by breaking the chain oxidation reactions, which can be an indicator of the antioxidant capacity of the essential oil.

\section{Peroxide Value (P.V)}

Table (2) shows the peroxide values of beef patties stored at $4^{\circ} \mathrm{C}$ for 10 days; it is noticed from the table that there are significant differences between the peroxide values of the treatments and the significant differences between the peroxide values of the treatments and the control sample at the probability level ( $\mathrm{P}<0.05)$. As well as peroxide values were observed to decrease in treatments B, C, D and E compared to treatment A (control sample), the value of peroxide on the second day was 10 mEq.kg oil ${ }^{-1}$ and on the tenth day, it was 22 mEq.kg oil ${ }^{-1}$, while the value of peroxide in the treatments B, C, D, E was lost. It was 11, 7.5, 6.5 and $5.2 \mathrm{mEq} . \mathrm{kg}$ oil $^{-1}$, respectively, for the tenth day, the height was slightly compared to treatment A (control sample). The peroxide values in $\mathrm{B}, \mathrm{C}, \mathrm{D}, \mathrm{E}$ were lower compared to treatment A (control sample). The increases in peroxide values were attributed to the composition and oxidation of meat fats during storage, which led to the formation of peroxides and ketones (Al-Tai, 1987).

The decrease in peroxide values in beef patties covered with potato starch films and in combination with rosemary oil by 2,4 and $6 \%$ may be due to the antioxidant activity of rosemary oil, which appeared by studying its antioxidant activity. 
Alansari / Basrah J. Agric. Sci., 33(2): 67-79, 2020

Table (2): Mean ( \pm Standard Deviation) of treatments peroxide values (millilitres equivalent for each kilogram of oil) of beef patties stored at $4{ }^{\circ} \mathrm{C}$ for 15 days covered with starch films installed with rosemary oil during different storage periods.

\begin{tabular}{|c|c|c|c|c|}
\hline \multirow{2}{*}{ Treatments } & \multicolumn{4}{|c|}{ Storage Periods/ day } \\
\cline { 2 - 5 } & $\mathbf{0}$ & $\mathbf{2}$ & $\mathbf{5}$ & $\mathbf{1 0}$ \\
\hline $\mathbf{A}$ & 0.00 & $10.00 \mathrm{a}$ & $13.50 \mathrm{a}$ & $22.33 \mathrm{a}$ \\
& & \pm 2.11 & \pm 2.10 & \pm 2.14 \\
\hline $\mathbf{B}$ & 0.00 & $7.20 \mathrm{~b}$ & $8.50 \mathrm{~b}$ & $11.00 \mathrm{~b}$ \\
& & \pm 1.22 & \pm 1.27 & \pm 1.19 \\
\hline $\mathbf{C}$ & 0.00 & $5.40 \mathrm{c}$ & $6.30 \mathrm{c}$ & $7.50 \mathrm{c}$ \\
& & \pm 0.89 & \pm 1.33 & \pm 1.23 \\
\hline D & 0.00 & $3.90 \mathrm{~d}$ & $5.10 \mathrm{~cd}$ & $6.50 \mathrm{~cd}$ \\
& & \pm 0.66 & \pm 1.21 & \pm 1.16 \\
\hline E & 0.00 & $2.60 \mathrm{~d}$ & $4.50 \mathrm{~d}$ & $5.20 \mathrm{~d}$ \\
& & \pm 0.59 & \pm 1.18 & \pm 1.13 \\
\hline
\end{tabular}

- $\quad$ Means with different letter vertically differ significantly at $\mathrm{P}<0.05$

= beef patties (control sample), $\mathrm{B}=$ beef patties covered with simple starch film $\mathrm{C}$, = beef patties covered with starch synthesis with rosemary oil $2 \% \mathrm{D},=$ beef patties covered with starch synthesis with mountain rosemary oil $4 \%$ E, = Beef patties covered with starch film with rosemary oil $6 \%$

The results were comparable to those found (Coskun et al., 2014). Peroxide values of beef patties coated with simple soybean films and films with oregano oil and stored in refrigerated oil for 12 days were found to decrease with increased storage time compared to uncovered beef patties. Vital et al. (2016) found that the active edible coating containing rosemary and oregano essential oils had potential applications in animal meat products to maintain/improve their characteristics during the shelf-life.

\section{Conclusion}

The results of this study demonstrated that rosemary oil can be successfully incorporated into potato starch edible films, which showed significant antioxidant properties. These properties may be due to its excellent antioxidant activities coming from the rosemary. Then corporations of rosemary oil to potato starch edible films may have supplementary applications in food packaging to improve the oxidative stability of foodstuffs.

\section{Acknowledgements}

My sincere thanks go to the Department of Food Science, College of Agriculture, and the Department of Chemistry, College of Science, the University of Basrah for helping me complete my research.

\section{Conflict to interest}

There is no conflict of interest.

\section{Reference}

Al-Hashimi, A. G., Altemimi, B. A., Lakshmanan, G., Francesco C., \& Naoufa, L. (2020). Development of a millet starch edible film containing clove essential oil. Journal of Foods, 9, 14pp. https://doi.org/10.3390/foods9020184.

Al-Tai, M. A. J. (1987). Meat and Fish Technology. Ministry of Higher Education Scientific Research, College of Agriculture, University of Basrah Press, 421pp. (In Arabic). http://en.uobasrah.edu.iq/

AOAC: Association of Official Analytical Chemists (2000). Official methods of analysis. 17th ed., Arlington. Washington, D.C., Vol. 1: 1-177. https://law.resource.org/pub/us/cfr/ibr/002/aoac. methods.1. 1990. 
Atares, L., \& Chiralt, A. (2016). Essential oils as additives in biodegradable films and coatings for active food packaging. Journal of Trend Food Science and Technology, 48, 51-62. https://doi.org/10.1016/j.tifs.2015.12.001

Bente, W., Tina, A., Ole, B., Andreas, B., Niall, Y., Lotte, J., \& Lars, T. (2006). Testing properties of potato starch from different scales of isolation-A ring test. Journal of Food Engineering, 79, 970978.https://doi.org/10.1016/j.jfoodeng.2006.01.090

Camo, J., Beltrán, J. A., \& Roncalés, P. (2008). Extension of the display life of lamb with an antioxidant active packaging. Journal of Meat Science, $\quad 80, \quad 1086-$ 1091.https://doi.org/10.1016/j.meatsci.2008.04.031

Coskun, B. K., Lu, E. C., Lu, Z. K., \& An, K. C. (2014). Antioxidant active packaging with soy edible films and oregano or thyme essential oils for oxidative stability of ground beef patties. Journal of Food Quality, 37, 203212.https://doi.org/10.1111/jfq.12089.

Díaz-Galindo, E. P., Nesic, A., Bautista-Baños, S., García, O. D. \& Cabrera-Barjas, G. (2020). Cornstarch-based materials incorporated with cinnamon oil emulsion physic-chemical characterization and biological activity. Journal of Foods, 9, 475: 10pp. https://doi:10.3390/foods9040475

Garrido, T., Etxabide, A., Peñalba, M., Caba, K. D., \& Guerrero, P. (2013). Preparation and characterization of soy protein thin films: Processing-properties correlation. Journal of Materials Letters, 105, 110112.https://doi.org/10.1016/j.matlet.2013.04.083

Haq, M. A., Hasnain, A., \& Azam, M. (2014). Characterization of edible gum cordia film: Effects of plasticizers. Journal of LWT-Food Science and Technology, 55, 163169.https://doi.org/10.1016/j.lwt.2013.09.027

Kadri, I. A., Zarai, Z., Chobba, I., Békir, A.; Gharsallah, N., Damak, M., \& Gdoura, R. (2011). Chemical constituents and antioxidant properties of Rosmarinus officinalis L. essential oil cultivated from South- Western Tunisia. Journal of Medicinal Plants Research, 5, 5999-6004. http://academicjournals.org/journal/JMPR/articlefull-text-pdf/79E707021011

Kudo, K., Onodera, S., Takeda, Y., Benkeblia, N., \& Shiomi, N. (2009). Antioxidative activities of some peptides isolated from hydrolyzed potato protein extract. Journal of Functional Food, 1, 170176.https://doi.org/10.1016/j.jff.2009.01.006

Li, J. H., Miao, J., Wu, J. L., Chen, S. F., \& Zhang, Q. Q. (2014). Preparation and characterization of active gelatine - based films incorporated with natural antioxidants. Journal of Food Hydrocolloid, 37 ,

166-173.

https://doi.org/10.1016/j.foodhyd.2013.10.015

Mali, S., Grossmann, M. V. E., Garcia, M. A., Martino, M. M., \& Zaritzky, N. E. (2006). Effects of controlled storage in thermal-mechanical and barrier properties of plasticized films from different starch sources. Journal of Food Engineering, 75, 453-460.

https://doi: 10.1016/j.jfoodeng.2005.04.031

Melo, C. D., Garcia, P. S., Grossmann, M. V. E., Yamashita, F., Antonia, L. H. D., \& Mali, S. (2011). Properties of extruded xanthan-starch-clay nanocomposite films. Journal of Brazilian Archives of Biology and Technolnology, 54, 12231333.https://10.1590/S15168913201100060009

Moss, M. (2003). Aromas of rosemary and lavender essential oils differentially affect cognition and mood in healthy adults. International Journal of Neuroscience, 113, 15-38. https://doi.org/10.1080/00207450390161903

Oyaizu, M. (1986). Studies on products of browning reaction. Journal of the Academy of Nutrition and Dietetics, 44, 307-315. https://doi.org/10.5264/eiyogakuzashi.44.307

Perazzo, K. K. N. C. L., Conceicao, A. C. D. C., dos Santos, J. C. P., Assis, D. J., Souza, C. O., \& Druzian, D. I. (2014). Properties and antioxidant action of actives Cassava starch films incorporated with green tea and palm oil extracts. Journal of PloSone, 9, 13pp. https://doi.org/10.1371/journal.pone.0105199.

Pirouzifard, M., Yorghanlu, R. A., \& Pirsa, S. (2019). Production of an active film based on potato starch containing Zedo gum essential oil of Salvia officinalis and study of physical, mechanical, and antioxidant properties. Journal of Thermoplastic Composite Materials, 33, 915937.https://doi.org/10.1177/0892705718815541

Ponce, A. G., Roura, S. I., Del Valle, C. E., \& Moreira, M. R. (2008). Antimicrobial and antioxidant activities of edible coatings enriched with natural plant extracts: In vitro and in vivo studies. Journal of Postharvest Biology and Technology, 49, 294300. https://doi.org/10.1016/j.postharvbio.2008.02.013

Resianingrum, R., Atmaka, W., Khasanah, L. U., Kawiji, R. U. \& Praseptiangga, D. (2016). Characterization of cassava starch-based edible film enriched with lemongrass oil (Cymbopogon 
citratus). Journal Nusantara Bioscience, 8, 278282.https://doi.org/10.13057/nusbiosci/n080223.

Ruiz-Navajas, Y., Viuda-Martos, M., Sendra, E., Perez-Alvarez, J. A., \& Fernández-López, J. (3013). In vitro antibacterial and antioxidant properties of chitosan edible films incorporated with Thymus moroderi or Thymus piperella essential oils. Journal Food Control, 30, 38639.https://doi.org/10.1016/j.foodcont.2012.07.052

Shan, B., Cai, Y. Z., Brooks, J. D., \& Corke, H. (2009). Antibacterial and antioxidant effects of five spice and herb extracts as natural preservatives of raw pork. Journal of the Science of Food and Agriculture, $\quad 89, \quad 1879-1885$. https://doi.org/10.1002/jsfa.3667

Senna, M. M., El-Shahat, H. A., \& El-Naggar, A. W. M. (2011). Characterization of gamma-irradiated plasticized starch/poly (vinyl alcohol) (PLST/PVA) blends and their application as protected edible materials. Journal of Polymer Research, 18, 763771. https://doi.org/10.1007/s10965-010-9473-6

SPSS, (2016). Statistical package for social science, version 24. Users guide for statistical,Chicago.https://www.ibm.com/analytics/s pss-statistics-software

Su, M. S., Shyu, Y. T. \& Chien, P. J. (2008). Antioxidant activities of citrus herbal product extracts. Journal of Food Chemistry, 111, 892-896. https://doi.org/10.1016/j.foodchem.2008.05.002.

Suput, D., Lazic, V., Pezo, L., Markov, S., Vastag, Z., Popovic, L., Radulovic, A.; Ostojic, S., Zatanovic,
S., \& Popovic, S. (2016). Characterization of starch edible films with different essential oils added. Journal of Food Nutrition Science, 66, 277-285. https://doi.org/https://doi.org/10.1515/pjfns-20160008

Tooraj, M., Hossein, T., Sayed, M. R. R. \& Abdol, R. O. (2012). Antibacterial, antioxidant, and optical properties of edible starch chitosan composite film containing Thymus kotschyanus essential oil. Journal of Veterinary Research Formulation, 3, 167-173.

https://europepmc.org/article/med/25610564

Veena, D., Mallika, N. E., Reddy, V. \& Sudheer, K. (2015). Quality of edible polymer films Incorporated with plant essential oils. International Journal of New Technologies in Science and Engineering, 2, 43-47. https://www.ijntse.com/archives.php

Vital, A. C. P., Guerrero, A., Monteschio, J. D., Valero, M. V., Carvalho, C. B., Filho, B. A. D., Madrona, G. S. M. \& Prado, I. N. (2016). Effect of edible and active coating (with rosemary and oregano essential oils) on beef characteristics and consumer acceptability. Journal of PloS One, 11, 15pp.https://doi.org/10.1371/journal.pone.0160535

Wang, J., Shang, J., Ren, F. \& Leng, X. (2010). Study of the physical properties of whey protein: Sericin protein-blended. Journal of European Food Research and Technology, 231, 109-116. https://doi.org/10.1007/s00217-010-1259-x

\title{
تحسين الفعالية المضادة للأكسدة لأغشية نثا البطاطا القابلة للأكل المدمجة بزيت اكليل الجبل Rosmarinuso fficinalis L.
}

\author{
بتول محمود الانصاري \\ قسم علوم الاغذية، كلية الزراعة، جامعة البصرة، العراق
}

المستخلص: الغرض من هذه الدراسة هو تقدير الفعالية المضادة للأكسدة للأغشية القابلة للأكل والمحضرة من النشا المستخلص من البطاطا والمركبة بالزيت العطري المستخلص من اوراق نبات اكليل الجبل بتركيز 2 و4 و 6 \% واستعمالها في تغليف اقراص

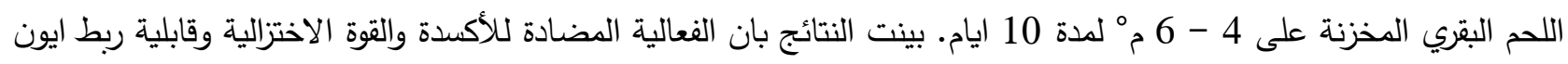

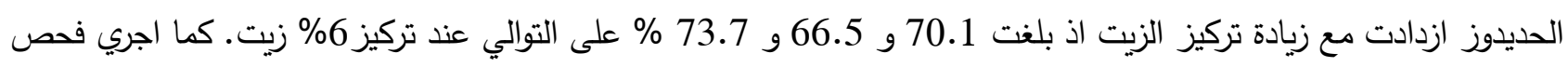
التحلل الوزني الحراري وتثخيص المجاميع الفعالة للأغشية البسيطة والمركبة بالزيت. وتمت متابعة التغيرات التي تحدث في في قيم التيز

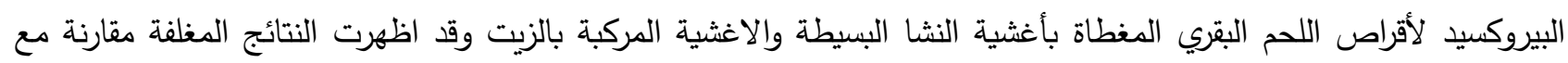
انخفاض قيم البيروكسيد في المعاملات المعاملة الضابطة التي لا تحتوي على الزبت. وكان تأثير اضافة زيت اكليل الجبل ايجابيا في اطالة مدة حفظ اقراص اللحم البقري طول مدة الخزن.

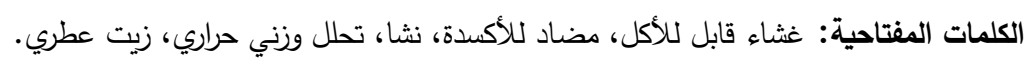

